\title{
Meningkatkan Hasil Belajar Ipa Materi Sistem Peredaran Darah Pada Manusia Melalui Pendekatan Saintifik Pada Siswa Kelas Viii C Mtsn Model Kota Sorong Tahun 2018
}

\author{
Miftahudin \\ MTsN Model of Sorong City. \\ Email: miftahudin823@gmail.com
}

\begin{abstract}
This study aims to determine the improvement of science learning out comes of circulatory system material in humans class VIII H MTsN Model Sorong City. Though the jus of scientific approach.

This type of the research is classroom Action Research ( CAR ) conducted collaboratively between researcher and teacher. The research was carried out in two cycles, each cycle consisting of four components. Namely plenning, action. Observation and refection. Data collection techniques used in this study were questionnaires, observation and test.

Data analysis was carried out in 3 stages : reduction, presentation, of data and drawing conclusion. The result of the study show that: (a) the use of scientific approaches can increase student learning ability of science learning participation. Increased ability of science lerning outcomes of circulatory of system material in humans can be seen through apects of observasing the first cycle of $76 \%$ increased to $84 \%$ In second cycle.

Participation in information collection (try) in the first cycle is $60 \%$ increased to 81 $\%$ in the second cycle. Participation in prosessing information (reasoning) in the first cycle by $53 \%$, increased to $72 \%$ in the second cycle (b) the use of scientific approaches can improve student learning outcomes in the fisrt cycle is 68,66 increasing to 76,37 in the second cycle.
\end{abstract}

Keywords: scientific approach, circulatory system in humans, and MTsN Model of Sorong City.

Abstrak: Penelitian ini bertujuan untuk mengetahui peningkatan Hasil Belajar hasil belajar IPA materi sistem peredaran darah pada manusia Siswa Kelas VIII C MTsN Model Kota Sorong melalui pemanfaatan pendekatan saintifik. Jenis penelitian ini adalah penelitian tindakan kelas (Classroom Action Research) yang dilakukan secara kolaboratif antara peneliti dengan guru. Penelitian dilaksanakan dalam dua siklus, masing-masing siklus terdiri dari empat komponen yaitu perencanaan, tindakan, pengamatan dan refleksi. Teknik pengumpulan data yang digunakan dalam penelitian ini adalah angket, observasi, dokumentasi dan tes. Analisis data dilakukan dalam 3 tahap yaitu reduksi, penyajian data serta menarik kesimpulan. Hasil penelitian menunjukkan bahwa: (a) pemanfaatan pendekatan saintifik dapat meningkatkan partisipasi belajar siswa. Peningkatan kemampuan hasi belajar hasil belajar IPA materi sistem peredaran darah pada manusia dapat dilihat melalui aspek mengamati siklus I sebesar $76 \%$ meningkat menjadi sebesar $84 \%$ pada siklus II. Partisipasi dalam menanya siklus 1 sebesar $66 \%$ meningkat menjadi sebesar $97 \%$ pada siklus 
II. Partisipasi dalam mengumpulkan informasi ( mencoba ) siklus I sebesar $61 \%$ meningkat menjadi sebesar $81 \%$ pada siklus II. Partisipasi dalam mengolah informasi ( menalar ) siklus I sebesar $53 \%$ meningkat menjadi sebesar $72 \%$ pada siklus II. Partisipasi dalam mengomunikasikan siklus I sebesar $50 \%$ meningkat menjadi sebesar $63 \%$ pada siklus II. (b) Pemanfaatan pendekatan saintifik dapat meningkatkan prestasi belajar siswa. Rata-rata hasil belajar siswa pada siklus I sebesar 68,66 meningkat menjadi 76,37 pada siklus II.

Kata kunci : pendekatan saintifik, sistem peredaran darah pada manusia, dan MTsN Model Kota Sorong

\section{Pendahuluan}

Tingkat pendidikan suatu masyarakat menunjukkan tingkat kemajuan wilayah itu. Di Indonesia setiap warga Negara berhak mendapatkan pendidikan yang layak, karena pendidikan itu sangat penting bagi setiap orang. Tujuan pendidikan yaitu untuk mempersiapkan manusia Indonesia agar memiliki kemampuan hidup sebagai pribadi dan warga negara yang beriman, produktif, kreatif, inovatif, dan afektif serta mampu berkontribusi pada kehidupan bermasyarakat, berbangsa, bernegara, dan peradaban dunia. Untuk mencapai tujuan tersebut maka mulai tahun 2013 diberlakukan kurikulum 2013 pada sekolah sasaran, walaupun MTsN Model Kota Sorong bukan salah satu sekolah sasaran untuk pelaksanaan kurikulum 2013, namun penenliti mencoba menyampaikan pembelajaran dengan menggunakan pendekatan saintifik yang merupakan pendekatan pembelajaran untuk kurikulum 2013.

Proses pembelajaran pada kurukulum 2013 yaitu menggunakan pendekatan ilmiah atau saintifik yang meliputi lima langkah pembelajaran . Lima langkah pendekatan saitifik yaitu mengamati, menanya, mencoba, menalar dan membuat jejaring. Terdapat tiga model pembelajaran yang sesuai dengan pendekatan saitifik yaitu model pembelajaran discovery learning (DL), project based learning ( $\mathrm{PjBL}$ ) dan problem based learning ( PBL )

Kurikulum 2013 mulai dilaksanakan pada beberapa sekolah sebagai sekolah sasaran mulai tahun ajaran 2013/2014. MTsN Model Kota Sorong bukan merupakan salah satu sekolah sasaran namun sebagai guru peneliti perlu mengikuti perkembangan dan mencoba hal-hal baru yang dapat meningkatkan potensi dan menambah wawasan serta mengembangkan profesionalisme. Karena pendekatan saitific baru mulai dilaksanakan dalam preses pembelajaran maka peneliti sebagai guru IPA mencoba melakukan penelitian tindakan kelas tentang pemanfaatan pendekatan saintifik untuk meningkatkan hasil belajar IPA siswa kelas VIII materi system peredaran darah pada manusia. Materi system peredaran darah pada manusia selama peneliti mengajar termasuk materi yang dianggap sulit oleh siswa, dengan ketuntasan ulangan harian materi tersebut hanya sekitar $40-50 \%$. Hal ini disebabkan karena sekitar $70 \%$ siswa tidak suka pelajaran IPA dan pelajaran IPA dianggap pelajaran yang sulit serta siswa belum ada keberanian untuk mengemukakan pendapat juga belum berani presentasi dari hasil kerjanya, hal tersebut yang menyebabkan nilai ulangan harian siswa banyak yang dibawah KKM atau tidak tuntas.

Berdasarkan uraian di atas maka penulis tertarik untuk melakukan penelitian dengan mengambil judul "Meningkatkan hasil belajar IPA materi sistem peredaran darah pada manusia melalui pendekatan saintifik siswa kelas VIII C MTsN Model Kota Sorong tahun 2018" 


\section{Metode Penelitian}

\subsection{Jenis Penelitian}

Penelitian ini merupakan penelitian tindakan kelas ( PTK ) yaitu pencermatan terhadap kegiatan belajar mengajar yang berupa sebuah tindakan, yang sengaja dimunculkan dan terjadi dalam sebuah kelas secara bersama. Dalam pelaksanaannya peneliti dapat melakukan penelitian tindakan kelas secara mandiri ataupun kolaboratif, akan tetapi tidak boleh menghambat kegiatan utama guru dalam proses pembelajaran.

Penelitian ini dilakukan secara kolaboratif dan partisipatif. Partisipatif dilakukan bersama mitra peneliti dalam melaksanakan penelitian ini. Selain partisipatif, peneliti juga berkolaborasi dengan guru, dan materi pelajaran untuk memperbaiki kekurangan-kekurangan dalam praktik pembelajaran. Dalam penelitian tindakan kelas ini, guru bertindak sebagai pelaksana tindakan sedangkan peneliti bertindak sebagai kolaborator.

Penelitian tindakan kelas ini dilakukan oleh peneliti, untuk mencoba menemukan suatu gagasan yang kemudian diterapkan dalam upaya perbaikan pada praktik pembelajaran yang dilakukan yaitu pembelajaran dengan menggunakan pendekatan saintifik yang diharapkan dapat memberikan perubahan ke arah perbaikan pada suatu proses pembelajaran. Dalam penelitian tindakan kelas ini terdiri atas empat kegiatan yang dilakukan dalam siklus berulang. Empat kegiatan utama yang ada pada setiap siklus, yaitu :

1. Perencanaan (planning), yaitu persiapan yang dilakukan untuk pelaksanaan penelitian tindakan kelas (PTK).

2. Tindakan (acting), yaitu deskripsi tindakan yang akan dilakukan, skenario kerja tindakan yang diterapkan.

3. Observasi (observing), yaitu kegiatan mengamati dampak atas tindakan yang dilakukan yaitu dapat dengan cara pengamatan, wawancara atau cara lain yang sesuai dengan data yang dibutuhkan.

4. Refleksi (reflecting), yaitu kegiatan evaluasi tentang perubahan yang terjadi atau hasil selama melakukan tindakan. Berdasarkan langkah ini akan dapat diketahui perubahan yang terjadi sehingga dapat mengatasi masalah secara signifikan. 
Siklus pada penelitian ini dapat digambarkan sebagai berikut :

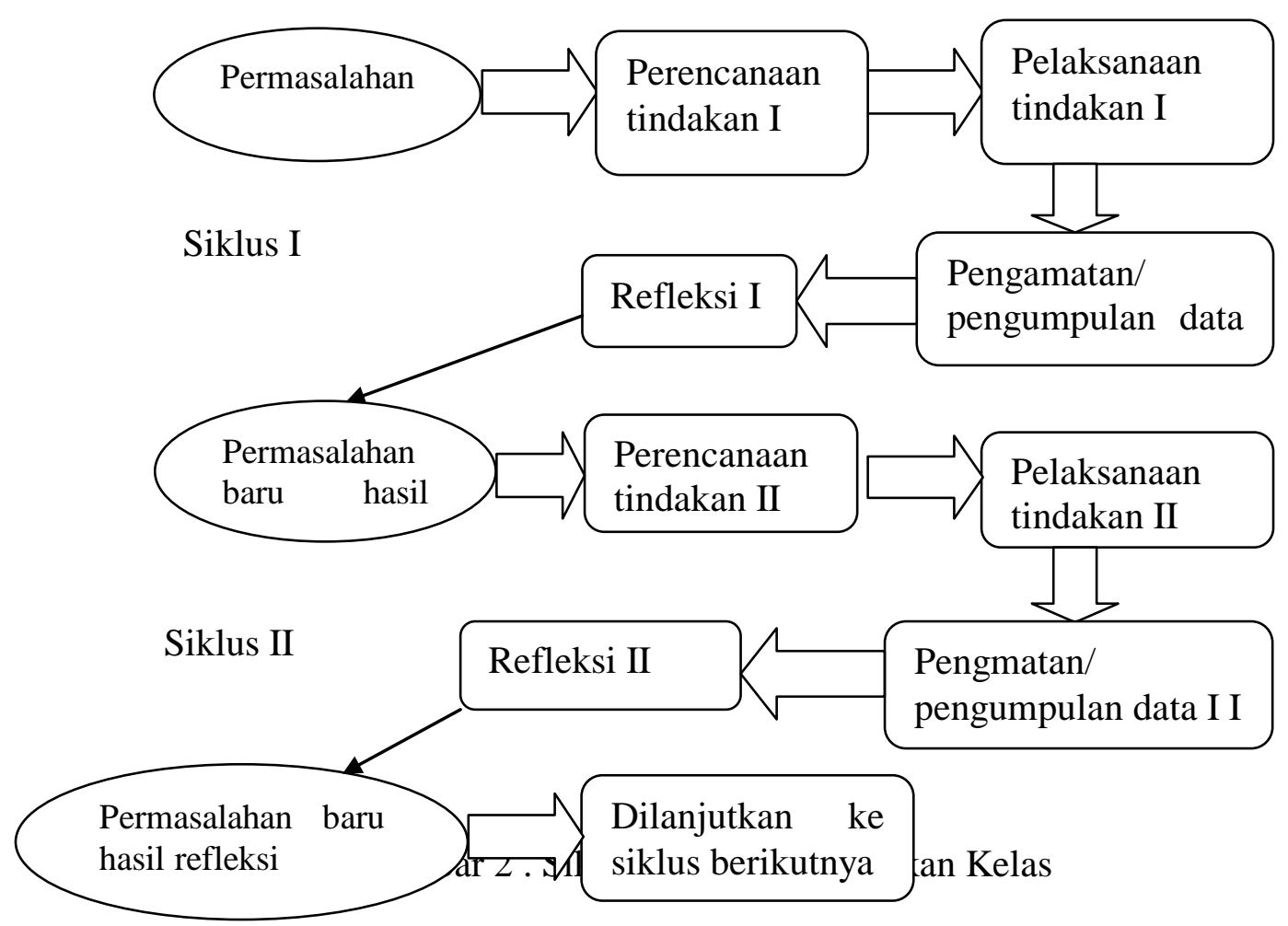

( Suharsimi Arikunto, 2013: 74)

\subsection{Teknik Analisis Data}

Analisis data yang digunakan dalam penelitian ini dilakukan terus menerus selama pengumpulan data berlangsung sampai pada akhir penelitian atau penarikan kesimpulan. Peneliti merefleksi hasil observasi terhadap proses pembelajaran yang dilaksanakan guru dan siswa di dalam kelas. Adapun yang dianalisis, sebagai berikut:

Cara menghitung persentase aktivitas siswa berdasarkan lembar observasi untuk tiap pertemuan adalah sebagai berikut :

skor Perolehan

(Jumlah siswa yang berpartisipasi

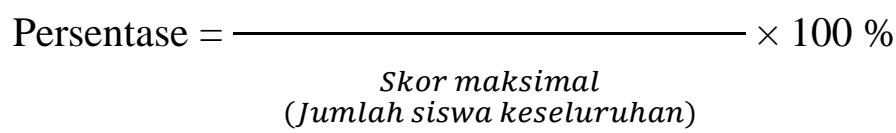

(Martinus, 2013: 49)

\section{Hasil Penelitian Dan Pembahasan}

\subsection{Hasil Penelitian}

\subsubsection{Hasil Tindakan}

\section{a. Hasil Observasi dan Pembahasan}

Selama kegiatan belajar mengajar berlangsung observer melakukan pengamatan secara langsung mengenai partisipasi yang ditunjukkan oleh siswa dalam mata pelajaran IPS . Dalam penelitian ini, unsur-unsur yang 
termasuk dalam partisipasi siswa atau keaktifan siswa meliputi mengamati, menanya, mengumpulkan informasi (mencoba), mengolah informasi (menalar) dan mengomunikasikan ( membuat jejaring ). Maka dari indikator-indikator tersebut,

hasil dari lembar pengamatannya sebagai berikut:

Tabel 2. Hasil Observasi Partisipasi Aktif Siswa pada Siklus 1

\begin{tabular}{|c|c|c|c|}
\hline \multirow[b]{2}{*}{ aspek yang diamati } & \multirow{2}{*}{$\begin{array}{c}\text { jumlah } \\
\text { siswa } \\
\text { total }\end{array}$} & \multicolumn{2}{|c|}{ partisipasi aktif } \\
\hline & & $\begin{array}{l}\text { jumlah } \\
\text { siswa }\end{array}$ & persentase \\
\hline Mengamati & 38 & 29 & $76 \%$ \\
\hline Menanya & 38 & 25 & $66 \%$ \\
\hline Mencoba & 38 & 23 & $61 \%$ \\
\hline Menalar & 38 & 20 & $53 \%$ \\
\hline Mengomunikasikan & 38 & 19 & $50 \%$ \\
\hline Jumlah & & 116 & $305,26 \%$ \\
\hline rata-rata & & 23,2 & $61,05 \%$ \\
\hline
\end{tabular}

Dari tabel dapat diketahui bahwa siswa yang mengamati sebanyak $76 \%$, menanya $66 \%$, mengumpulkan informasi (mencoba) $61 \%$, mengolah informasi (menalar) $53 \%$, mengomunikasikan (membuat jejaring) $50 \%$,

\subsubsection{Hasil Tes}

Berdasarkan rata-rata siswa pada post test 1 dapat diketahui sebesar $(68,66)$.hal tersebut menunjukan bahwa nilai siswa pada siklus 1 di atas, belum mencapai criteria keberhasilan, karena masih terdapat 24 siswa belum mencapai KKM, sehingga perlu dilanjutkan dengan siklus berikutnya yaitu siklus II.

\subsubsection{Pengamatan terhadap partisipasi aktif siswa (observasi)}

Selama kegiatan pembelajaran berlangsung observer melakukan pengamatan secara langsung mengenai partisipasi yang ditunjukkan oleh siswa dalam permainan bola voli. Pada siklus II ini tingkat partisipasi aktif siswa sudah mulai menunjukkan adanya peningkatan yang relatif stabil dan hampir semua siswa sudah memperhatikan, berpartisipasi dan mengikuti proses pembelajan. Semua ini dapat dilihat dengan adanya peningkatan dari hampir semua aspek yang diamati. Hasil dari pengamatan siswa pada siklus II, dapat dilihat pada tabel berikut :

\section{Tabel 4.}

\section{Hasil Observasi Partisipasi Aktif Siswa pada Siklus 1I}

\begin{tabular}{|c|c|c|c|}
\hline \multirow[b]{2}{*}{ aspek yang diamati } & \multirow{2}{*}{$\begin{array}{c}\text { jumlah siswa } \\
\text { total }\end{array}$} & \multicolumn{2}{|c|}{ partisipasi aktif } \\
\hline & & $\begin{array}{c}\text { jumlah } \\
\text { siswa }\end{array}$ & persentase \\
\hline Mengamati & 38 & 32 & $84 \%$ \\
\hline
\end{tabular}




\begin{tabular}{||l|c|c|c||} 
Menanya & 32 & 31 & $97 \%$ \\
\hline Mencoba & 32 & 26 & $81 \%$ \\
\hline Menalar & 32 & 23 & $72 \%$ \\
\hline Mengomunikasikan & 32 & 20 & $63 \%$ \\
\hline Jumlah & & $\mathbf{1 3 2}$ & $\mathbf{3 9 6 , 7 1 \%}$ \\
\hline rata-rata & & $\mathbf{2 6 , 4}$ & $\mathbf{7 9 , 3 4 \%}$ \\
\hline
\end{tabular}

Dari tabel dapat diketahui bahwa siswa yang mengamati sebanyak $84 \%$, menanya $97 \%$, mengumpulkan informasi ( mencoba) $81 \%$, mengolah informasi (menalar) 72\%, mengomunikasikan (membuat jejaring) $63 \%$.

\subsubsection{Hasil Tes}

Berdasarkan rata-rata hasil belajar antara tes pada siklus I dan siklus II yang diketahui bahwa pada tes II (76,37 mempunyai rata-rata lebih tinggi dibandingkan dengan rata-rata pada tes yang dilakukan di siklus I $(68,66)$. Hal ini menunjukkan adanya peningkatan pada hasil belajar pada siklus II dalam mata pelajaran IPA. Berdasarkan rata-rata pada siklus II di atas, kriteria keberhasilan sudah tercapai karena lebih dari $75 \%$ siswa telah mencapai KKM bahkan 92 \% siswa mencapai KKM, hal ini menunjukkan adanya pencapaian tingkat keberhasilan sesuai dengan kriteria keberhasilan yang telah ditetapkan.

\subsubsection{Pembahasan Partisipasi Aktif Siswa}

Hasil penelitian tindakan siklus I dan siklus II dengan penggunaan pendekatan scaintifik menunjukkan adanya peningkatan terhadap aktivitas belajar siswa. Peningkatan terjadi pada observasi siklus II di mana dalam observasi ini yang diamati adalah partisipasi aktif siswa. Dari hasil observasi diperoleh data aktivitas siswa sebagai berikut:

Tabel 6 Peningkatan Partisipasi Aktif Siklus I dan Siklus II

\begin{tabular}{||l|c|c|c||}
\hline aspek yang diamati & siklus I & siklus II & $\begin{array}{c}\text { peningkatan } \\
\text { partisipasi }\end{array}$ \\
\hline Mengamati & $76 \%$ & $84 \%$ & $8 \%$ \\
\hline Menanya & $66 \%$ & $97 \%$ & $31 \%$ \\
\hline Mencoba & $61 \%$ & $81 \%$ & $20 \%$ \\
\hline Menalar & $53 \%$ & $72 \%$ & $19 \%$ \\
\hline Mengomunikasikan & $50 \%$ & $63 \%$ & $13 \%$ \\
\hline \multicolumn{1}{|c|}{ jumlah } & $\mathbf{3 0 5 \%}$ & $\mathbf{3 9 7 \%}$ & $\mathbf{9 1 \%}$ \\
\hline rata-rata & $\mathbf{6 1 \%}$ & $\mathbf{7 9 \%}$ & $\mathbf{1 8 \%}$ \\
\hline
\end{tabular}

Berdasarkan hasil observasi yang dapat dilihat dari tabel di atas dapat dilihat adanya peningkatan frekuensi dari siklus I ke siklus II. Setiap indikator masing-masing siklus juga mengalami peningkatan. Pada siklus I dan siklus II peningkatan partisipasi siswa yang tinggi yaitu menanya , karena terjadi peningkatan sebesar $31 \%$ dan peningkatan partisipasi aktif 
siswa yang rendah adalah indikator mengamati karena hanya terjadi peningkatan sebesar $8 \%$.

Jadi dapat disimpulkan bahwa dengan penggunaan pendekatan scaintifik dalam mata pelajaran matematika dapat meningkatkan partisipasi aktif siswa dalam proses pembelajaran. Untuk membuktikannya dapat dilihat dalam diagram berikut:

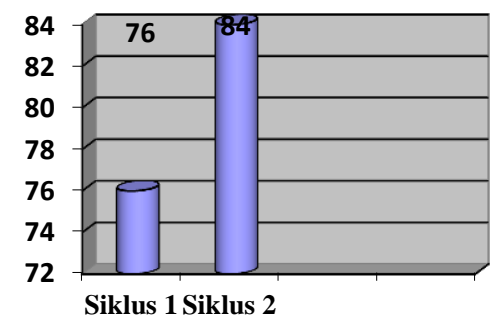

\section{Gambar 3.. Diagram Persentase Mengamati}

Pada indikator mengamati persentase siswa dalam kelas pada siklus I sebesar $76 \%$ dan pada siklus II sebesar $84 \%$. Pada diagram di atas menunjukkan bahwa partisipasi aktif siswa untuk kegiatan mengamati dari siklus I ke siklus II persentasenya meningkat sebesar $8 \%$

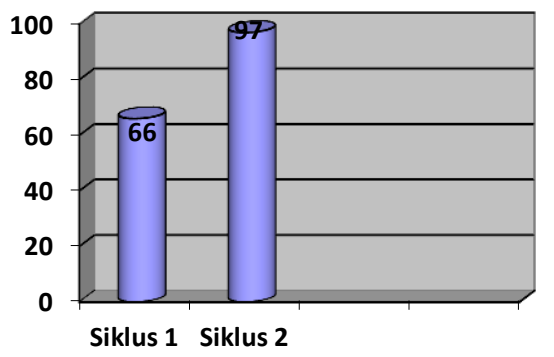

\section{Gambar 4. Diagram Persentase Menanya}

Pada indikator menanya persentase siswa dalam kelas pada siklus I sebesar $66 \%$ dan pada siklus II sebesar $97 \%$. pada diagram di atas menunjukkan bahwa partisipasi siswa dari siklus I ke siklus II terjadi peningkatan sebesar $31 \%$.

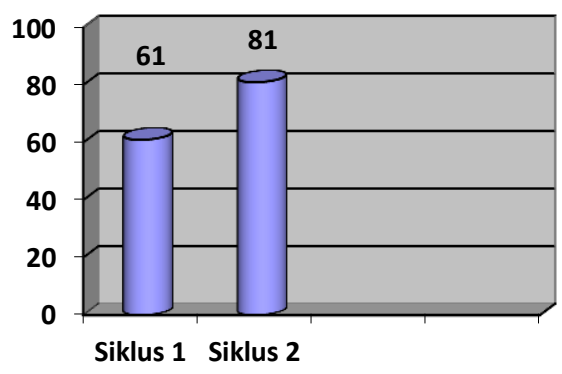

\section{Gambar 5 Diagram persentase mengumpulkan informasi ( mencoba)}

Pada indikator mengumpulkan informasi (mencoba) persentase siswa dalam kelas pada siklus I sebesar $61 \%$ dan pada siklus II sebesar $81 \%$. Pada diagram di atas menunjukkan bahwa terjadi peningkatan partisipasi aktif siswa untuk kegiatan mengumpulkan informasi (mencoba) dari siklus I ke siklus II sebesar $20 \%$, karena siswa menjadi tertarik dengan menggunakan pendekatan scaintifik. 


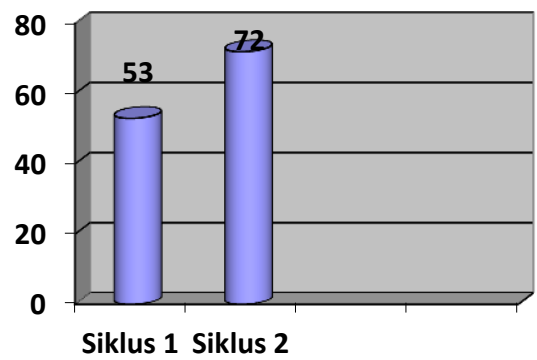

Gambar 6. Diagram persentase mengolah informasi ( menalar )

Pada indikator mengolah informasi ( menalar ) persentasae siswa dalam kelas pada siklus I sebesar $53 \%$ dan pada siklus II sebesar $72 \%$. Pada diagram di atas menunjukkan bahwa partisipasi aktif siswa untuk mengolah informasi ( menalar) dari siklus I ke siklus II juga mengalami peningkatan sebesar $19 \%$.

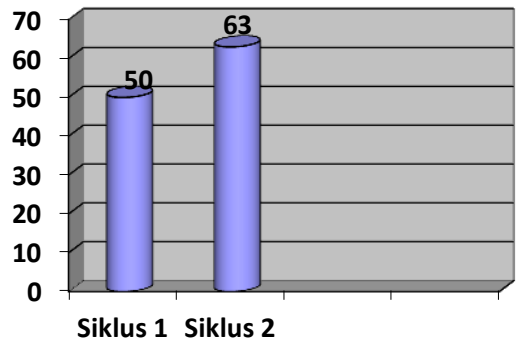

\section{Gambar 6. Diagram Persentase Mengomunikasikan}

Pada indikator kegiatan mengomunikasikan persentase siswa dalam kelas pada siklus 1 sebesar $50 \%$ dan pada siklus II sebesar $63 \%$. Pada diagram di atas menunjukkan bahwa partisipasi aktif siswa untuk kegiatan mengomunikasikan dari siklus I ke siklus II persentasenya meningkat sebesar $13 \%$.

\subsubsection{Pembahasan Prestasi Belajar Siswa}

Penilaian yang digunakan pada setiap siklus adalah dengan menggunakan tes dan dilaksanakan pada setiap akhir siklus dengan soal-soal yang sesuai dengan materi yang diberikan kepada siswa. Hal ini dilakukan untuk mengukur sejauh mana siswa dapat menguasai materi yang telah disampaikan menggunakan pendekatan scaintifik. Hasil penelitian tindakan siklus I dan II dengan penggunaan pendekatan scaintifik menunjukkan adanya peningkatan terhadap prestasi belajar siswa.

Dari pernyataan tersebut, dapat disimpulkan bahwa dengan menggunakan pendekatan scaintifik dapat menaikkan ingatan yang berarti dapat meningkatkan pestasi beajar siswa.

Setelah dilakukan penelitian yang dimulai dari tahapan siklus I, sampai pada tahapan siklus II dapat dilihat adanya peningkatan partisipasi aktif dan prestasi belajar siswa dengan menggunakan pendekatan scaintifik. Berdasarkan pemaparan prestasi belajar di atas dapat diberikan penjelasan bahwa telah terjadi peningkatan prestasi belajar siswa dari siklus I mencapai rata-rata $68,66 \%$ naik menjadi rata-rata $76,37 \%$ pada tahap siklus II. Dari rata-rata tersebut dapat diketahui peningkatan rata-rata 7,71\% dari siklus I ke siklus II. Dapat disimpulkan bahwa dengan penggunaan pendekatan scaintifik 
pada mata pelajaran IPA dapat meningkatkan prestasi belajar siswa walaupun peningkatannya masih relatif kecil.

Dari hasil penelitian menunjukkan bahwa terdapat peningkatan ratarata nilai hasil belajar dari siklus I sebesar 68,66 sedangkan pada siklus II meningkat menjadi sebesar 76,37. Peningkatan juga terlihat pada nilai tertinggi yang diperoleh siswa dari siklus I sebesar 75 menjadi 80 pada siklus II.

Dalam penelitian terlihat juga peningkatan nilai terendah yang diperoleh siswa dari siklus I sebesar 65, meningkat menjadi sebesar 68 pada siklud II. Jumlah ketuntasan individu yang mencapai Kriteria Ketuntasan Minimal (KKM) juga meningkat dari siklus I sebanyak 14 siswa menjadi 35 siswa pada siklus II. Sehingga dapat dikatakan bahwa peningkatan persentase ketuntasan individu pada Siklus I sebesar $40 \%$ siswa yang telah mencapai ketuntasan atau mencapai Kriteria Ketuntasan Minimal (KKM), menjadi 92 $\%$ siswa yang tuntas pada siklus II. Sehingga dapat disimpulkan bahwa penggunaan pendekatan saintifik pada pembelajaran materi sistem peredaran darah pada manusia dapat meningkatkan prestasi belajar siswa dan dapat meningkatkan partisipasi aktif siswa dalam mengikuti proses pembelajaran.

\section{Kesimpulan dan Saran}

\subsection{Kesimpulan}

Berdasarkan hasil analisis data dan pembahasan yang telah peneliti lakukan, aktivitas belajar siswa kelas VIII C di MTsN model Kota Sorong untuk mata pelajaran Ilmu Pengetahuan Alam ( IPA ) dapat ditarik kesimpulan sebagai berikut:

1. Penerapan pembelajaran dengan menggunakan pendekatan scaintifik dapat meningkatkan hasil belajar siswa materi sistem peredaran darah pada manusia siswa kelas VII $A_{1}$ MTsN model Kota Sorong dilihat dari adanya peningkatan persentase,

2. Peningkatannya dapat dilihat dari hasil observasi pada siklus I dan siklus II. Pada Aspek mengamati siklus I sebesar $76 \%$ dan siklus II sebesar $84 \%$. Aspek menanya siklus 1 sebesar $66 \%$ dan siklus II sebesar $97 \%$. Aspek mengumpulkan informasi (mencoba) siklus I sebesar $61 \%$ dan siklus II sebesar $81 \%$. Aspek mengolah informasi (menalar) siklus I sebesar $53 \%$ dan pada siklus II sebesar $72 \%$. Aspek mengomunikasikan siklus I sebesar $50 \%$ dan siklus II sebesar $63 \%$. Hal ini menunjukkan bahwa terjadi peningkatan terhadap partisipasi aktif dalam kegiatan mengamati, menanya, mencoba, menalar dan mengomunikasikan walaupaun peningkatannya masih relatif kecil.

3. pendekatan scaintifik juga dapat meningkatkan hasil belajar pada mata pelajaran IPA di kelas. Peningkatan hasil belajar ini dapat dilihat dari adanya perubahan nilai rata-rata yang diperoleh siswa pada setiap akhir siklus. Nilai rata-rata yang diperoleh siswa pada siklus I sebesar 68,66 dan siklus II sebesar 76,37. Hal tersebut membuktikan bahwa dengan menggunakan pendekatan scaintifik dapat meningkatkan prestasi belajar siswa. 


\subsection{Saran}

Berdasarkan hasil penelitian dan pembahasan maupun kesimpulan di atas, dapat diajukan beberapa saran:

1. Guru perlu mengupayakan partisipasi belajar siswa dengan cara melanjutkan pembelajaran dengan pendekatan scaintifik pada mata pelajaran IPA untuk pertemuan-pertemuan selanjutnya agar siswa tertarik dalam memahami materi yang diberikan dalam proses pembelajaran sehingga partisipasi siswa dapat bertahan bahkan meningkat.

2. Guru perlu mengupayakan prestasi belajar siswa dengan cara melanjutkan penggunaan pendekatan scaintifik pada mata pelajaran IPA untuk pertemuanpertemuan selanjutnya agar siswa tertarik dalam memahami materi yang diberikan dalam proses pembelajaran sehingga prestasi siswa dapat bertahan bahkan meningkat.

\section{Daftar Pustaka}

Dergibson S. dan Sugiarto, 2000, Metode Statistika, PT Gramedia Pustaka Utama, Jakarta.

Modul, 2013, Materi Implementasi Kurikulum 2013, Jakarta, Kemdikbud

Negoro dan B. Harahap, 1998, Ensiklopedia IPS, Balai aksara

Riduwan. (2009). Skala Pengukuran Variabel-Variabel Penelitian. Bandung: Alfabeta.

Rochiati Wiriaatmadja. (2009). Metode Penelitian Tindakan Kelas. Bandung: PT. Remaja Rosdakarya.

Saeful Karim dkk (2008) Belajar IPA untuk kelas VIII, Jakarta : Depdikbud

Slameto. (2010). Belajar Faktor-Faktor yang Mempengaruhi. Jakarta: Rineka Cipta.

Sugihartono. (2007). Psikologi Pendidikan. Yogyakarta: UNY .Press.

Suharsimi Arikunto. (2009). Dasar-dasar Evaluasi Pendidikan (Edisi Revisi, cetakan 7). Jakarta: Bumi Aksara

Suharsimi Arikunto, dkk. (2013). Penelitian Tindakan Kelas. Jakarta : Bumi Aksara.

Sumadi Suryabrata. (2006). Psikologi Pendidikan. Jakarta: PT. Raja Grafindo Persada.

Suryobroto. (1997). Proses Belajar Mengajar di Sekolah. Jakarta: PT . Rineka Cipta.

Susilo. (2007). Panduan Penelitian Tindakan Kelas. Yogyakarta: Pustaka Book Publlisher. 